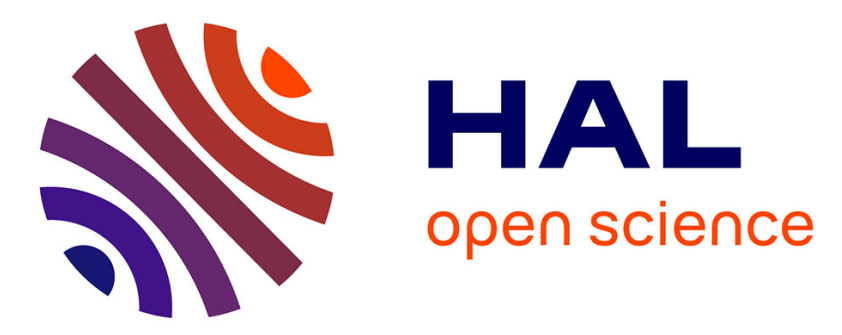

\title{
Effets of Cobalt Oxide-Iron Oxide Ratios on the Catalytic Activity of Cobalt Ferrite Spinel Catalysts
}

\author{
A. Said, K. Abd El-Salaam, E. Hassan, A. El-Awad, M. Abd El-Wahab
}

\section{To cite this version:}

A. Said, K. Abd El-Salaam, E. Hassan, A. El-Awad, M. Abd El-Wahab. Effets of Cobalt Oxide-Iron Oxide Ratios on the Catalytic Activity of Cobalt Ferrite Spinel Catalysts. Journal de Physique IV Proceedings, 1997, 07 (C1), pp.C1-687-C1-688. 10.1051/jp4:19971282 . jpa-00254995

\section{HAL Id: jpa-00254995 https://hal.science/jpa-00254995}

Submitted on 1 Jan 1997

HAL is a multi-disciplinary open access archive for the deposit and dissemination of scientific research documents, whether they are published or not. The documents may come from teaching and research institutions in France or abroad, or from public or private research centers.
L'archive ouverte pluridisciplinaire HAL, est destinée au dépôt et à la diffusion de documents scientifiques de niveau recherche, publiés ou non, émanant des établissements d'enseignement et de recherche français ou étrangers, des laboratoires publics ou privés. 


\title{
Effects of Cobalt Oxide-Iron Oxide Ratios on the Catalytic Activity of Cobalt Ferrite Spinel Catalysts
}

\author{
A.A. Said, K.M. Abd El-Salaam, E.A. Hassan, A.M. El-Awad and M.M.M. Abd El-Wahab \\ Chemistry Department, Faculty of Science, Assiut University, Assiut, Egypt
}

\begin{abstract}
The cobalt ferrite spinels $\mathrm{Co}_{\mathrm{x}} \mathrm{Fe}_{3-\mathrm{x}} \mathrm{O}_{4}(0.6<\mathrm{x}<2.4$ ) have been prepared by coprecipitation. The structures of the catalysts were characterized by DTA, X-ray diffraction, surface area and electrical conductivity measurements. The catalytic decomposition of isopropanol was carried ont at $325^{\circ} \mathrm{C}$ using. a flow system. The results obtained revealed that the activity and selectivity of the catalysts are strongly affected by the structure oi the ferrite spinel formed as a result of the solid - solid interaction between $\mathrm{Fe}_{2} \mathrm{O}_{3}$ and $\mathrm{Co}_{3} \mathrm{O}_{4}$. The normal spinel formed at $(x=1)$ gives low activity and low selectivity in comparison with the spinels deviated from the stoichiometry. Additionally, a little change in catalytic behaviour observed on increasing the calcination temperature from $400^{\circ}$ to $600^{\circ} \mathrm{C}$. Correlations between the composition, electronic and catalytic properties of the catalysts are reported.
\end{abstract}

\section{INTRODUCTION}

In an increasing number of areas of technology, industrial progress is related to the understanding of the factors influencing the reactivity of the solids. The co-existence of different oxidation states of transition metal ions occurs naturally in minerals and is frequently induced during the preparation of solid state catalysts [1]. The distribution of cations of ferrite spinel among available tetrahedral ( $t$ ) and octahedral (o) sites are of considerable industrial interest due to their catalytic activity [2-5]. However, it was already reported that the wide variation in both catalytic and electrical properties of ferrite spinels is related mainly to their stoichiometry $[3,4]$. The aim of this work is to correlate the catalytic activity and electrical conductivity of ferrite spinel to their structure changes.

\section{Experimental}

Analar grade chemicals were used throughout. Mixed samples of iron and cobalt hydroxides ( $\mathrm{x}$ the mole contents of $\mathrm{Co}^{2+}$ are $0.6,0.8,1.0,1.5,2.0,2.2$ and 2.4 ) were prepared according the method reported elsewhere [6]. Defferential thermal analysis (DTA) was carried out using an automatically recording thermobalance, type $160 \mathrm{KS}$ (Germany). X-ray diffraction (XRD) of the thermal products were recorded using a Philips diffractometer (Model PW2103). Surface area measurements were determined at $-196^{\circ} \mathrm{C}$ with the help of conventional volumetric apparatus. IR spectra of solid catalysts were recorded in $1600-200 \mathrm{~cm}^{-1}$ region with the spectrophotometer Perkin-Elemer Model 599B, using KBr technique. The electrical conductivity measurements were made as described previously [7]. The catalytic activity determination was carried out in a conventional fixed - bed flow type reactor. 


\section{Results and discussion}

The prepared catalysts are characterized by DTA, XRD, IR and SBET measurements. The resuits showed that cobalt ferrite spinels were formed at a calcination temperature of $400^{\circ} \mathrm{C}$ and their compositions depend on the $x$ ratio and the calcination temperature. The electrical conductivity $(\sigma)$ of these spinels was measured in air and in presence of IPA and cited in Table 1 .

Table 1. Variation of $\log \sigma$ with $x$ ratio of $\mathrm{Co}-\mathrm{Fe}$ mixtures calcined at $500^{\circ} \mathrm{C}$ and measured at $300^{\circ} \mathrm{C}$

\begin{tabular}{llllllll} 
x ratio & 0.6 & 0.8 & 1.0 & 1.5 & 2.0 & 2.2 & 2.4 \\
\hline $\log \sigma(\mathrm{air})$ & -4.4 & -4.6 & -4.3 & -4.1 & -3.8 & -3.6 & -3.4 \\
\hline $\log \sigma(\mathrm{air}+\mathrm{IPA})$ & -3.5 & -3.3 & -4.5 & -4.3 & -4.7 & -4.6 & -4.5
\end{tabular}

It appears that the conductance in the rich region with normal spinel is slightly changed in the presence and absence of IPA. The catalytic activity of spinel catalysts calcined at $500^{\circ} \mathrm{C}$ was tested at a reaction temperature of $325^{\circ} \mathrm{C}$ using the decomposition of IPA. Figure 1 shows that the inverse spinel catalysts are active and selective towards the formation of acetone. The formation of inverse spinel is accompanied with the occurrence of redox couples within the octahedral cites which are responsible for the chemisorption of alcohol and eventually also its decomposition. On the other hand. the sharp decrease of acetone yield for the ratio $\mathrm{x}=1$ may be attributed to the formation of normal spinel which is accompanied with a small electron exchange within its structure [4].



Figure 1: Variation of IPA conversion $(0)$, actone yield $(\Delta)$ and proplyne yield $(a)$ (all in $\%$ ) with the catalyst composition calcined at $500^{\circ} \mathrm{C}$ for $3 \mathrm{~h}$.

\section{References}

[1] Bloom E., Kometani T.Y. and Mikchell J.W., J. Inorg. Nucl. Chem., 401 (1978) 403-410.

[2] Hassan E.A., Abd El-Salaam K.M. and Said A.A., Bull. Chem. Soc. Jpn., 61 (1988) 1331 1334.

[3] Said A.A., Hassan E.A., El-Awad A.M., Abd E1-Salaam K.M. and Abd El-Wahab M.M.M., J. Chem. Technol., 60 (1994) 161-170.

[4] Abd El-Salaam K.M., Said A.A., El-Awad A.M., Hassan E.A. and Abd El-Wahab M.M.M., Collect. Czech. Chem. Commun., 59 (1994) 1939-1950.

[5] Rajram R.R. and Sermon P.A., J. Chem. Soc. Faraday Trans I, 81 (1995) 2577-2585.

[6] Tseung A.C.C. and Galdstein J.R., J.Mater. Sci., 7 (1972) 1383-1389.

[7] Said A.A., Hassan E.A. and Abd El-Salaam K.M., Surf. Technol., 20 (1983) 123-130. 